ISSN 1817-3721, E-ISSN 1818-8745

Plant Tissue Cult. \& Biotech. 29(1): 25-32, 2019 (June)

(CBangladesh Assoc. for Plant Tissue Culture \& Biotechnology

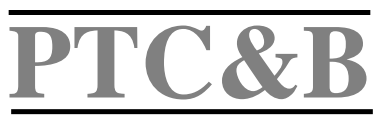

\title{
Effect of 2, 4-D and Picloram on Somatic Embryogenesis in Carica papaya var. P-7-9
}

\section{Kulbhushan Chaudhary and Jai Prakash*}

Division of Fruits and Horticultural Technology, ICAR - Indian Agricultural Research Institute, New Delhi 110012, India

Key words: Auxin, Carica papaya, Somatic embryogenesis

\begin{abstract}
Immature zygotic embryos of Carica papaya L. var. P-7-9 were inoculated on half-strength MS with different concentrations of 2,4-D and picloram alone and their combinations. The highest induction (80\%) of somatic embryogenesis was MS supplemented with 2,4-D $(7.0 \mathrm{mg} \Lambda)$ followed by $2,4-\mathrm{D}(4.0 \mathrm{mg} \Lambda)+$ picloram $(1.0 \mathrm{mg} \Lambda)$ but no embryogenesis was observed in auxin-free medium. The addition of osmoticum such as PEG and ABA significantly increased the maturation of somatic embryos. BAP, TDZ and NAA were used for shoot induction. Combination of $2.0 \mathrm{mg} / \mathrm{BAP}$ and $0.5 \mathrm{mg} / \mathrm{NAA}$ was found significantly better for shoot bud proliferation and $70 \%$ multiplication. The percentage of germinating embryos was enhanced significantly when the MS fortified with $\mathrm{GA}_{3}(0.5$ $\mathrm{mg}$ /). However, the high frequency of embryo germination and plantlets formation were obtained with 2,4-D (4.0 mg $\Lambda)+$ picloram $(1.0 \mathrm{mg} \Lambda)$.
\end{abstract}

\section{Introduction}

Papaya (Carica papaya L.) is an economically important crop which is cultivated in tropical and sub-tropical parts of the world. The fruit is consumed worldwide as fresh fruits, while the immature fruits are used as culinary preparations (Malabadi et al. 2011). Papaya is also a good source of calcium, vitamin A and C and its leaf juice has been used for treatment of malaria and dengue (Ahmad et al. 2011). Traditionally, papaya is propagated through seeds for commercial plantations, which generates heterogenous populations resulting in reduction of fruit production. Papaya cultivation is also severely hampered by papaya ring spot virus (PRSV) and papaya leaf curl virus (PLCV). Early attempts to inter cross cultivated papaya with other species yielded fruit with non-viable seeds (Jimenez and Horowitz 1958). Crosses between C. papaya and V. cauliflora have been reported but the hybrids have low viability and vigour and most of the crosses turned out to be sterile (Manshardt and Wenslaff 1989).

*Author for correspondence: <jaiprakash@iari.res.in> DOI: https://doi.org/10.3329/ptcb.v29i1.41976 
To overcome these problems tissue culture technique is applied which is an important tool in a crop improvement programmes. de Bruijne et al. (1974) reported somatic embryogenesis in papaya later many reports have been published (Fitch et al. 1990, Chen et al. 1991). The somatic cell contains genetic information to form a complete and fertile plant (Merkle et al. 1987). Micropropagation by somatic embryogenesis acts as a powerful tool for genetic improvement of any plant species because of its single cell origin (Bhansali 1990, Jha et al. 2007). Several reports are available on somatic embryogenesis of C. Papaya L. is on varieties like Kapoho, Sunset, Waimanalo etc. which are not commonly cultivated in India. The frequency of response to somatic embryogenesis within a species may vary considerably from one genotype to another and also different in vitro and ex vitro conditions may be required for each genotype. Hence, the present study was carried out with the main objective of developing plant regeneration protocol in C. Papaya var. P-7-9, that can be used for further genetic transformation.

\section{Materials and Methods}

Immature green papaya fruits were harvested from field grown papaya var. P-7-9 maintained in germplasm block at Division of Fruits and Horticultural Technology, Indian Agricultural Research Institute, New Delhi. Fruits were picked between 90 and 100 days old after flower anthesis. The immature fruits were washed thoroughly under running tap water and soaked in 3\% (v/ ) sodium hypochlorite for $20 \mathrm{~min}$ and then rinsed three to five times with sterile double-distilled water. The fruits were then surface sterilized with ethanol $(70 \% \mathrm{v} N)$ in the laminar air-flow hood and bisected with the sterilized blade to excise immature seed. These seeds were subsequently excised with the help of a pair of forceps and scalpel and immature embryos were picked by gently pressing the seed from sarcotesta and used as explants. Half-strength of MS with $0.4 \mathrm{~g} /$ glutamine, $(0.5 \mathrm{~g} \Lambda)$ casein hydrolysate, $(60.0 \mathrm{~g} \Lambda)$ sucrose and $(0.8 \%)$ agar was used. The $\mathrm{pH}$ was adjusted to 5.8 before adding agar and prior to autoclaving $\left(1.05 \mathrm{~kg} / \mathrm{cm}^{3}\right)$ at $121^{\circ} \mathrm{C}$ for $15 \mathrm{~min}$. The culture medium for callus induction was supplemented auxin i.e., 2,4-D (5.0, 6.0 and $7.0 \mathrm{mg} \Lambda$ ), picloram $(5.0,6.0$ and $7.0 \mathrm{mg} \Lambda$ ) and their combination to evaluate their effects on the production of embryogenic callus. MS without any plant growth regulator served as control. Excised immature zygotic embryos were inoculated in the disposable Petri dish $(90 \times 10 \mathrm{~mm})$ (Tarsons, Mumbai) and each treatment consisted of 100 embryos. The Petri dish was sealed with parafilm and kept in the dark at $25-27^{\circ} \mathrm{C}$ for 4 - 6 weeks. Sub-culture was carried out after every 15 - 20 days interval on to the same medium until somatic embryo induction.

After callus induction phase in the dark, the well proliferated modular calli were transferred on to the germination medium (half-strength of MS, $30.0 \mathrm{~g} / \mathrm{sucrose}$ and 0.8 $\mathrm{g} /$ agar) supplemented with different concentration of BAP, TDZ and NAA. The cultures 
were incubated to light condition $\left(54 \mu \mathrm{mol} \mathrm{m}^{-2} \mathrm{~s}^{-1}\right)$ for $16 \mathrm{hrs} \mathrm{light} \mathrm{and} 8 \mathrm{hrs}$ dark period at $25 \pm 0.5^{\circ} \mathrm{C}$. Within $3-4$ weeks, heart shape embryos converted into cotyledonary embryos. Thereafter, regenerated shoots which were $3-4 \mathrm{~cm}$ in length, having at least three expanded leaves and 2 - 3 nodes, were excised from the shoot clumps and transferred to the rooting medium consisting of half-strength MS with different concentrations of IBA (0.5 - $1.5 \mathrm{mg} /)$ and $100 \mathrm{mg} /$ activated charcoal. The entire rooting experiment was initially under complete darkness for 15 days, and then transferred to the light condition. Cultures for shoot multiplication and rooting were raised in $150 \times 25$ mm glass jars with PP cap (Borosil, India), containing $50 \mathrm{ml}$ medium (Fig. 1). Well rooted
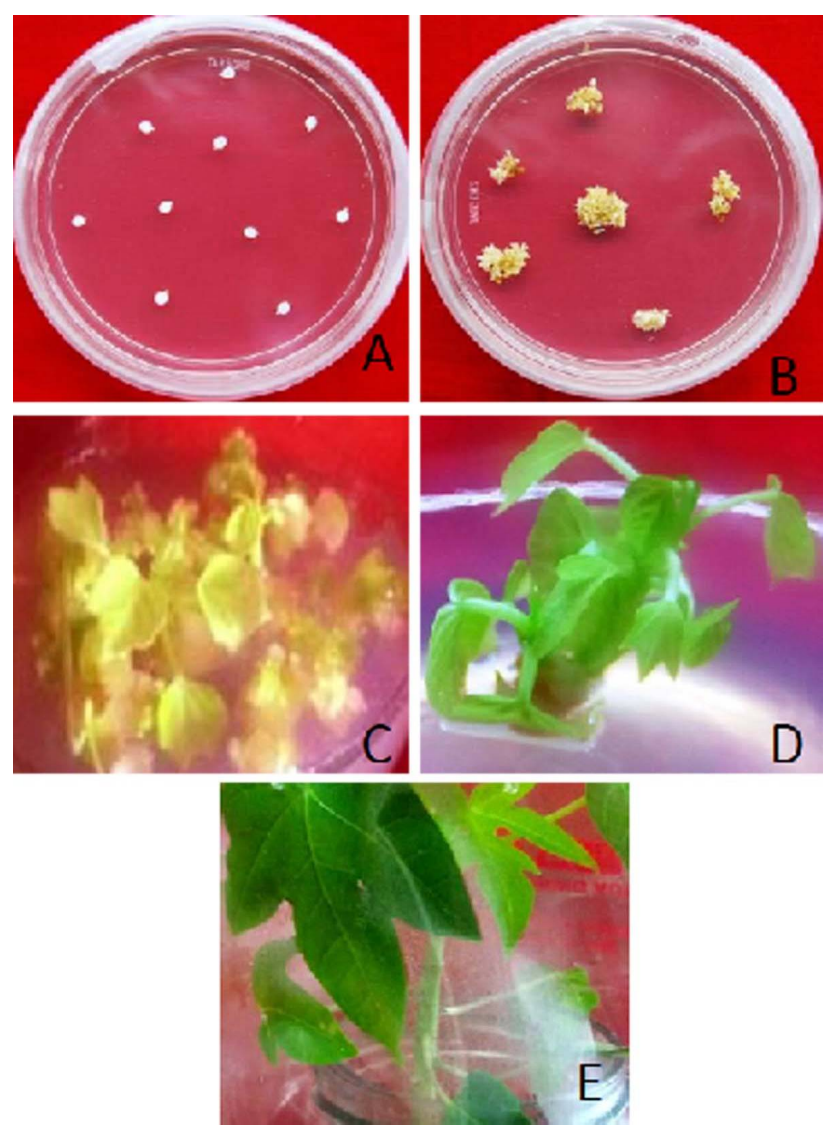

Fig. 1. (A) Immature zygotic embryo, (B) somatic embryos after 2 - 3 weeks, (C) regerminated plantlets from somatic embryos, (D) well-developed elongated shoot, (E) a complete plant of Carica papaya.

plantlets were removed from the culture and washed with sterile distilled water to remove adhering agar from the roots and dipped in $0.01 \%$ carbendazin (fungicide) for 15 $\mathrm{min}$. The rooted plantlets were transferred to the plastic pots $(10 \times 9 \mathrm{~cm})$ containing a mixture of autoclaved soil, sand and vermiculite (1:1:1 by volume). Each pot was 
covered with a transparent polythene bags (for maintain a high relative humidity) and maintained in a plant growth chamber at $25^{\circ} \mathrm{C}$ under $16 / 8 \mathrm{hrs}$ photoperiod illuminations. For hardening the plants, the humidity was gradually reduced by making holes in the plastic bags. After 3 - 4 weeks of acclimatization, plants were transferred to greenhouse for further acclimatization. The data were subjected to analysis ANOVA and means were separated using DMRT at a $>5 \%$ probability level. Variability of data has also been expressed as the mean \pm standard error (SE).

\section{Results and Discussion}

The present investigation is well-documented study of somatic embryogenesis in Carica papaya var. P-7-9. The various concentrations of auxin had influenced the somatic embryogenesis. The immature zygotic embryos inoculated in different media to produce callus from 7 - 12-day inoculation. The first indication of embryogenesis was an initial swelling of globular structures which later developed into somatic embryo. 2,4-D in combination of glutamine leads to induction and proliferation of adventives embryony. Glutamine and casein hydrolysate has been shown to improve somatic embryogenesis in several plant species such as rice, chickpea (Yin et al. 1993, Vani and Reddy 1996). Similar finding were reported by Zouine and El Hadrami (2006) using glutamine with 2, 4-D which was better for somatic embryo induction. After two weeks of inoculation an unorganized mass of callus was formed from the surviving immature embryo explant. Several creamish-white to yellow thread like embryos appeared within six weeks of culture. For maturation, embryos were transferred to the maturation medium (halfstrength of MS fortified with PEG 4000 (20 mg/) and abscisic acid (ABA) $1.0 \mathrm{mg} /$ ). Earlier studies showed that the application of PEG as an osmoticum in maturation media promoted the accumulation of storage reserves (storage proteins, lipids and polypeptides). This has proven effective in increasing somatic embryo germination and conversion (Attree et al. 1992, Capuna and Debergh 1997). The combined use of PEG and ABA has also enhanced embryo quality by increasing desiccation tolerance and preventing precocious germination (Vahdati et al. 2008). By the end of 8 - 9 weeks of culture, embryogenic calli matured and proliferated rapidly. A few embryogenic calli were induced with picloram 6.0 and $7.0 \mathrm{mg} \Lambda$ having light brown, loose and watery texture which showed moderate embryogenic response. On the other hand, calli induced in medium containing 2,4-D was yellow, creamy, modular and compact. In hormone-free medium immature zygotic embryos did not produce callus but a few embryos germinated. The highest percentage of callus induction (80) was recorded with 2,4-D 7.0 $\mathrm{mg} /$ (Table 1) in comparison to other auxin concentrations used. Embryos at various distinct stages (globular, heart-shaped, torpedo and cotyledonary) of developments were observed during the study. Present authors found that 2,4-D was most responsive giving the highest $(80 \%)$ callus induction rate. It was also found that, the prolonged presence on 
2,4-D in the culture medium prevented embryo formation and subsequently decreased their germination.

Earlier BAP has been demonstrated to be more potent for proliferation but TDZ has been commonly used for shoot induction in many woody plant species. Culture of mature embryos on germination medium amended with various concentrations of BAP

Table 1. Effect of different concentrations and combinations of 2, 4-D and picloram on somatic embryogenesis of Carica papaya var. P-7-9.

\begin{tabular}{|c|c|c|c|c|c|}
\hline $\begin{array}{l}\text { Growth } \\
\text { regulators }\end{array}$ & $\begin{array}{l}\text { Conc. level } \\
(\mathrm{mg} \Lambda)\end{array}$ & $\begin{array}{l}\text { Days taken } \\
\text { for callus } \\
\text { initiation }\end{array}$ & $\begin{array}{l}\text { Response } \\
(\%)\end{array}$ & $\begin{array}{c}\text { Embryogenesis } \\
(\%)\end{array}$ & $\begin{array}{c}\text { Regeneration } \\
(\%)\end{array}$ \\
\hline \multirow[t]{4}{*}{$2,4-\mathrm{D}$} & 0.0 & 0 & 0.0 & 0.0 & 0.0 \\
\hline & 5.0 & 9 & $66 \pm 1.5 b c$ & $60 \pm 0.5 \mathrm{~d}$ & $55 \pm 3.6$ \\
\hline & 6.0 & 8 & $70 \pm 2.0 \mathrm{~cd}$ & $70 \pm 1.1 \mathrm{e}$ & $49 \pm 0.5 b$ \\
\hline & 7.0 & 8 & $80 \pm 1.0 \mathrm{~d}$ & $80 \pm 0.6 f$ & $56 \pm 0.8 d$ \\
\hline \multirow[t]{4}{*}{ Picloram } & 0.0 & 0 & 0.0 & 0.0 & 0.0 \\
\hline & 5.0 & 11 & $65 \pm 2.3 b c$ & $41 \pm 1.0 \mathrm{ab}$ & $49 \pm 0.1 \mathrm{a}$ \\
\hline & 6.0 & 10 & $74 \pm 2.9 \mathrm{~cd}$ & $42 \pm 1.6 \mathrm{ab}$ & $51 \pm 0.6 b c$ \\
\hline & 7.0 & 10 & $79 \pm 0.6 \mathrm{~d}$ & $50 \pm 0.6 c$ & $53 \pm 1.2$ cdef \\
\hline \multirow[t]{4}{*}{ 2,4-D+ picloram } & 0.0 & 0.0 & 0.0 & 0.0 & 0.0 \\
\hline & $\begin{array}{l}2,4 \text {-D } 4.0+ \\
\text { picloram } 1.0\end{array}$ & 9 & $69 \pm 1.2 \mathrm{c}$ & $70 \pm 1.8 \mathrm{e}$ & $72 \pm 1.4 h$ \\
\hline & $\begin{array}{l}2,4 \text {-D } 4.0+ \\
\text { picloram } 2.0\end{array}$ & 10 & $65 \pm 0.6 b c$ & $66 \pm 1.4 \mathrm{de}$ & $61 \pm 0.8 g$ \\
\hline & $\begin{array}{l}2,4-\mathrm{D} 4.0+ \\
\text { picloram } 3.0\end{array}$ & 12 & $65 \pm 2.8 b c$ & $66 \pm 1.6 \mathrm{de}$ & $60 \pm 0.6 g$ \\
\hline \multirow[t]{4}{*}{ Picloram+2,4-D } & 0.0 & 0 & 0.0 & 0.0 & 0.0 \\
\hline & $\begin{array}{l}\text { Picloram } 4.0+ \\
2,4-D 1.0\end{array}$ & 9 & $57 \pm 1.7 \mathrm{ab}$ & $41 \pm 3.4 \mathrm{ab}$ & $52 \pm 1.4$ cde \\
\hline & $\begin{array}{l}\text { Picloram } 4.0+ \\
2,4-\mathrm{D} 2.0\end{array}$ & 11 & $52 \pm 1.4 a$ & $36 \pm 6.0 \mathrm{a}$ & $52 \pm 1.2 \mathrm{~cd}$ \\
\hline & $\begin{array}{l}\text { Picloram } 3.5+ \\
2,4-D 3.5\end{array}$ & 12 & $65 \pm 2.8 b c$ & $47 \pm 1.4 b c$ & $55 \pm 1.4 \mathrm{def}$ \\
\hline
\end{tabular}

Each value represents the mean of + SE of three independent replications with 100 explants each. Value having the same letter in a column is not significantly different.

and TDZ supplemented with NAA resulted in a differential response. After two weeks, yellowish-greenish callus followed by differentiation of small multiple shoots become visible. The result showed that $2.0 \mathrm{mg} \Lambda$ BAP with $1.0 \mathrm{mg} \Lambda$ NAA was effective in giving maximum shoot germination ( $85 \%$ ) followed by $1.5 \mathrm{mg} / \mathrm{TDZ}$ with $0.5 \mathrm{mg} / \mathrm{NAA}$ with (78\%) (Table 2). The synergistic combination of BAP and NAA not only promoted shoot 
multiplication, but also secondary embryo formation. The secondary somatic embryos were more synchronized than primary embryos. Somatic embryos that did not develop into plantlets became abnormally enlarged and formed callus on their surface. Some embryos formed translucent, non-embryogenic callus consisting of hyperhydritic cells,

Table 2. Effect of various concentrations of different cytokines on the multiplication of shoots regenerated from callus of Carica papaya var. P-7-9.

\begin{tabular}{llll}
\hline $\begin{array}{l}\text { Growth } \\
\text { regulators }\end{array}$ & $\begin{array}{l}\text { Concentration } \\
\text { level }(\mathrm{mg} \Lambda)\end{array}$ & $\begin{array}{l}\text { Shooting frequency } \\
(\%)\end{array}$ & $\begin{array}{l}\text { Number of } \\
\text { shoot/explants }\end{array}$ \\
\hline BAP +NAA & $0.0+0.0$ & 0.0 & 0.0 \\
& $1.0 \pm 0.5$ & $65 \pm 1.3 \mathrm{a}$ & $3.9 \pm 0.3 \mathrm{~b}$ \\
& $1.5 \pm 1.0$ & $69 \pm 1.0 \mathrm{~g}$ & $5.7 \pm 0.1 \mathrm{~d}$ \\
TDZ +NAA & $2.0 \pm 1.0$ & $85 \pm 1.5 \mathrm{c}$ & $6.5 \pm 0.1 \mathrm{e}$ \\
& $2.5 \pm 1.5$ & $57 \pm 0.8 \mathrm{e}$ & $3.3 \pm 0.6 \mathrm{a}$ \\
& $1.0 \pm 0.5$ & $61 \pm 0.6 \mathrm{~cd}$ & $4.0 \pm 0.0 \mathrm{~b}$ \\
& $2.5 \pm 1.0$ & $78 \pm 1.1 \mathrm{~h}$ & $5.5 \pm 0.1 \mathrm{~d}$ \\
& $2.0 \pm 1.0$ & $68 \pm 0.7 \mathrm{~g}$ & $4.9 \pm 0.0 \mathrm{c}$ \\
& $2.5 \pm 1.0$ & $60 \pm 0.3 \mathrm{~b}$ & $2.8 \pm 0.2 \mathrm{~h}$ \\
\hline
\end{tabular}

Each value represents the mean of + SE of three independent replications with 100 explants each. Values having the same letter in a column are not significantly different.

which lost regeneration potential. The combination of BAP and $\mathrm{GA}_{3}$ not only promoted the growth of shootlets but also enhanced the frequency of root induction. It was obvious from the present study that both BAP and $\mathrm{GA}_{3}$ were essential for higher embryo germination rate (data not shown). The beneficial effect of $\mathrm{GA}_{3}$ on somatic embryo generation has been earlier reported for other plant species too (Sivanesan et al. 2011, Raomai et al. 2014). With the increase in concentration of BAP beyond optimal level, resulted in a decline shootlets proliferation rate, indicating an adverse effect on shoot multiplication. Similar results were observed by Mohiuddin et al. (1998) which showed that high concentration of BAP $(3.0 \mathrm{mg} A)$ induced abnormal plantlets in Cucumis melo. Later, Madhulatha et al. (2004) reported that higher concentration of BAP and Kn caused necrosis and reduction in shoot organogenesis during in vitro multiplication of Nendran banana. In the present study too, it was also observed that TDZ $3.0 \mathrm{mg} /$ induced more numbers of shoot buds than BAP but failed to develop into complete shoot. Root induction is mostly difficult in the woody plant species. In contradictory, the combination of IBA and activated charcoal was found to be ideal for root initiation. Rooting was initiated within 10 - 15 days with formation of a single white root. For maintaining biological ability of the cells and cellular proliferation of lateral roots supplementation of IBA is essential (Stefanicic et al. 2005). Activated charcoal in medium 
helps in balancing the $\mathrm{pH}$ level as well as improves the nitrogen absorption by the shoots, and also induces rooting (Thomas 2008). It was also found that $1 / 4$ strength medium was superior as compared to half-strength medium for rooting. The addition of activated charcoal led to the significantly increase in shoot and root multiplication by absorption of phenolic compounds and excessive auxins (Madhusudanan et al. 2000, von Aderkas et al. 2002). The concentration of $1.0 \mathrm{mg} / \mathrm{IBA}$ was found superior as compared to other concentrations in terms of roots produced per explants.

The present study demonstrated that the 2,4-D plays an important role in somatic embryogenesis. Further the treatment induced embryogenesis but the per cent embryogenesis and average time varied among various concentrations of supplements. Individually 2,4-D and picloram could induce callus but maximum plantlets were obtained only in the combination of 2,4-D $4.0 \mathrm{mg} /$ + picloram $1.0 \mathrm{mg} /$. Hence, this was selected as most potent treatment. Jayanthi et al. (2015) also reported that highest embryogenesis with a combination of 2,4-D + picloram in tenera group of oil palms.

\section{Acknowledgement}

The authors are thankful to ICAR-Indian Agricultural Research Institute, New Delhi for providing financial support.

\section{References}

Ahmad N, Fazal H, Ayaz M, Abbasi BH, Mohammad I and Fazal L (2011) Dengue fever treatment with Carica papaya leaves extracts. Asian Pak. J. Trop. Biomed. 1: 330-333.

Attree SM, Pomeroy MK and Fowke LC (1992) Manipulation of conditions for the culture of somatic embryos of white spruce for improved triacylglycerol biosynthesis and desiccation tolerance. Planta 187: 395-404.

Bhasali R (1990) Somatic embryogenesis and regeneration of plantlets in pomegranate. Ann. Bot. 66: 249-254.

Capuna M and Debergh PC (1997) Improvement of the maturation and germination of chestnut somatic embryos. Plant Cell Tissue Organ Cult. 48: 23-29.

Chen MH, Chen CC, Wang DN and Chen FC (1991) Somatic embryogenesis and plant regeneration from immature embryos of Carica papaya $\times$ Carica cauliflora cultured in vitro. Can. J. Bot. 69: 1913-1918.

deBruijne E, DeLanghe E and van Rijck R (1974) Action of hormones and embryoid formation in callus cultures of Carica papaya. Int. Symp. Crop Protection 39: 637-645.

Fitch MMM and Manshardt RM (1990) Somatic embryogenesis and plant regeneration from immature zygotic embryos of papaya (Carica papaya L.). Plant Cell Reports 9: 320-324.

Jayanthi M, Susanthi B, Mohan NM and Mandal PK (2015) In vitro somatic embryogenesis and plantlet regeneration from immature male inflorescence of adult dura and tenera palms of Elaeis guineensis (Jacq.). Springer Plus 4: 256 
Jha TB, Mukherjee P and Datta MK (2007) Somatic embryogenesis in Jatropha curcas Linn., an important biofuel plant. Plant Biotechnol. Rep. 1: 135-140.

Jimenez H and Horowitz S (1958) Cruzabilidad entre species de carica. Argon. Trop. 7: 207-215.

Madhulatha P, Anbalagan M, Jayachandran S and Sakthivel N (2004) Influence of liquid pulse treatment with growth regulators on in vitro propagation of banana (Musa spp. AAA). Plant Cell Tissue Organ Cult. 76: 189-192.

Madhusudhanan K and Rahiman BA (2000) The effect of activated charcoal supplemented media to browning of in vitro cultures of piper species. Biol. Plantrum 43: 297-299.

Malabadi RB, Kumar SV, Mulgund GS and Nataraja K (2011) Induction of somatic embryogenesis in papaya (Carica papaya). Res. Biotechnol. 2: 40-55.

Manshardt RM and Wenslaff TF (1989) Interspecific hybridization of papaya with other Carica species. J. Amer. Soc. Hart. Sci. 114: 689-694.

Merkle SA, Wetzstein HY and Sommer HE (1987) Somatic embryogenesis in tissue culture of pecan. Hort. Science 22: 128-130.

Mohiuddin AKM, Chowdhury MKU, Abdulla ZC, Harikrishna K and Napis S (1998) Factors affecting in vitro adventitious shoot regeneration of muskmelon (Cucumis melo L.) cv. birdie. Sci. Int. 10: 143-146.

Raomai S, Kumaria S and Tandon P (2014) Plant regeneration through direct somatic embryogenesis from immature zygotic embryos of the medicinal plant, Paris polyphylla Sm. Plant Cell Tissue Organ Cult. 118: 445-455.

Sivanesan I, Lim MY and Jeong BR (2011) Somatic embryogenesis and plant regeneration from leaf and petiole explants of Campanula punctata Lam. var. rubriflora Makino. Plant Cell Tissue Organ Cult. 107: 365-369.

Stefancic M, Stampar F and Ostrec G (2005) Influence of IAA and IBA on root development and quality of prunus 'GiSelA 5' leafy cuttings. Hort. Science 40: 2052-2055.

Thomas $\mathbf{R}$ (2008) The role of activated charcoal in plant tissue culture. Biotechnol. Adv. 26: 618-631.

Vahdati K, Bayat S, Ebrahimzadeh H, Jariteh M and Mirmasoumi M (2008) Effect of exogenous ABA on somatic embryo maturation and germination in Persian walnut (Juglansregia L). Plant Cell Tissue Organ Cult. 93: 163-171.

Vani AKS and Reddy VD (1996) Morphogenesis from callus cultures of chickpea, Cicerarietinum L. Indian J. Exp. Biol. 34: 285-287.

vonAderkas P, Label M and Lelu M (2012) Charcoal affects early development and hormonal concentrations of somatic embryos of hybrid larch. Tree Physiol. 22: 431-434.

Yin Y, Li S, Chen Y, Guo S, Tian W and Chen Y (1993) Fertile plants regenerated from suspension culture-derived proroplasts of an indica-type rice (Oryzasativa L.). Plant Cell Tissue Organ Cult. 32: 61-68.

Zouine J and Hadrami IEI (2007) Effects of 2,4-D, glutamine and BAP on embryogenic suspension culture of date palm. Sci. Hortic. 112: 221-226.

(Manuscript received on 2 March, 2019; revised on 7 April, 2019) 